\title{
A CLINICO-AETIOLOGICAL STUDY OF CASES OF ERYTHRODERMA ATTENDING TERTIARY CARE HOSPITAL IN NORTH-EAST INDIA
}

\author{
Jahnabi Boruah', Bhaskar Gupta² \\ 1 Postgraduate Resident, Department of Dermatology, Silchar Medical College, Silchar, Assam, India. \\ 2Professor and HOD, Department of Dermatology, Silchar Medical College, Silchar, Assam, India.
}

ABSTRACT
BACKGROUND
Erythroderma is the term used for any inflammatory skin disease that affects more than $90 \%$ of the body surface area. ${ }^{1}$ It has many
underlying causes and finding the aetiology helps in proper management of cases.

Aim- To study and analyse the different causes of erythroderma.

\section{MATERIALS AND METHODS}

The study was performed in Silchar Medical College and Hospital, Silchar, Assam. A total of 30 cases of erythroderma were studied with respect to epidemiological, clinical and histological finding.

\section{RESULTS}

Among 30 cases, 21 were male and 9 were female patients with male-to-female ratio of 2.3: 1 and mean age of incidence was found to be $53.26 \%$ yrs. In our study, the most common aetiology was found to be psoriasis $(n=14,46.6 \%)$, atopic dermatitis $(n=5$, $16.6 \%)$, drug-induced erythroderma $(n=3,10 \%)$, allergic contact dermatitis $(n=3,10 \%)$, dermatophytosis and pemphigus foliaceus (one case each) and 3 idiopathic cases (10\%).

\section{CONCLUSION}

Although clinical presentation of most of the patients was similar, a detailed history, physical examination and histopathological examination helped us to reach most of the diagnosis.

\section{KEY WORDS}

Erythroderma, Clinico-Aetiological Study, North-East India.

HOW TO CITE THIS ARTICLE: Boruah J, Gupta B. A clinico-aetiological study of cases of erythroderma attending tertiary care hospital in North-East India. J. Evolution Med. Dent. Sci. 2018;7(42):4523-4525, DOI: 10.14260/jemds/2018/1009

\section{BACKGROUND}

Erythroderma or exfoliative dermatitis is any inflammatory skin disease that affects more than $90 \%$ of the body surface. ${ }^{1}$ Primary erythroderma arises on normal looking skin due to an underlying systemic disorder including malignancy or because of a drug reaction, while secondary erythroderma arises from pre-existing dermatoses like psoriasis, atopic dermatitis, Pityriasis rubra pilaris and actinic dermatosis. ${ }^{2}$ Early diagnosis of the aetiology helps in proper management of cases and also treating the underlying associated pathology, thus decreasing morbidity of patients.

\section{MATERIALS AND METHODS}

It is a descriptive study which was conducted in a period of 12 months from July 2017 to June 2018 to find the aetiology in patients of exfoliative dermatitis admitted in Silchar Medical College and Hospital, Silchar, Assam. In the given period 30 cases of erythroderma were admitted and were evaluated with detailed clinical history including history of drug intake.

'Financial or Other Competing Interest': None.

Submission 31-08-2018, Peer Review 27-09-2018,

Acceptance 03-10-2018, Published 15-10-2018.

Corresponding Author:

Dr. Jahnabi Boruah,

Postgraduate Resident,

Department of Dermatology,

Silchar Medical College,

Silchar-788014, Assam, India.

E-mail: jahnavii777@gmail.com

DOI: $10.14260 /$ jemds $/ 2018 / 1009$
Patients were further evaluated after taking proper consent. Complete physical examination including cutaneous examination was done. Laboratory investigations were also done which included complete haemogram including total count, differential count, ESR, peripheral blood film for abnormal cell, blood glucose level, kidney function test, liver function test, serum total protein and fraction, serum total IgE in selected cases, routine urine examination, chest x-ray, ultrasonography whole abdomen to rule out any internal malignancy and patch test in selected cases. Biopsy of skin was done in all the cases and FNAC of lymph node were done when required.

\section{RESULTS}

In our study among the thirty cases 21 were male and 9 were female patients with male-to-female ratio of 2.3: 1 ; mean age of incidence was found to be 53.26 yrs.; median of the age is $56.5 \mathrm{yrs}$. and interquartile range of age is $17 \mathrm{yrs}$. The disease was observed maximum in patients at $5^{\text {th }}$ and $6^{\text {th }}$ decade of their life, though the age ranges from 15 yrs. to 69 yrs. Erythema and scaling were present in all the cases, pruritus ( $90 \%$ cases), oedema (53\% cases) and fever (46\% cases). In our study, most common aetiology of erythroderma was found to be Psoriatic erythroderma, all of them had preexisting psoriasis (Fig. 1). Erythroderma due to Atopic dermatitis was found to be the second most common cause (Fig. 2). Among the 3 cases of drug induced erythroderma, 2 of whom gave history of intake of Carbamazepine and 1 gave history of intake of Phenytoin. Among the Erythroderma due to allergic contact dermatitis, two were due to occupational exposure to cement and one with contact to parthenium 
weed. All of them were confirmed by patch testing once erythroderma subsided. Erythroderma due to Pemphigus foliaceus and Dermatophytosis were found to be rare. In 3 of the cases, no causes of erythroderma could be established.

\section{Laboratory Finding}

Mild anaemia, raised ESR, leucocytosis and hypoalbuminaemia were the common findings. Elevated serum IgE levels were noted in cases of atopic dermatitis. Histopathological examination of skin biopsy were suggestive of clinical diagnosis in majority of patients, except 3 idiopathic cases which showed only mild spongiosis with non-specific inflammatory infiltrate (Table 1). In dermatophytosis case, skin scraping for $\mathrm{KOH}$ mount revealed hyaline septate fungal hyphae. In 17 patients of enlarged lymph node, FNAC was done in 13 patients and findings were suggestive of dermatopathic lymphadenopathy.

\begin{tabular}{|c|c|c|c|c|}
\hline $\begin{array}{l}\text { Sl. } \\
\text { No. }\end{array}$ & Causes & $\begin{array}{l}\text { No. } \\
\text { (\%) }\end{array}$ & $\begin{array}{c}\text { Mean } \\
\text { Age } \\
\text { (Year) }\end{array}$ & Pathological Finding \\
\hline 1. & 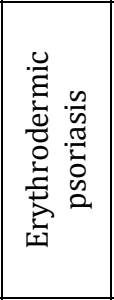 & $\begin{array}{c}14 \\
(46.6 \%)\end{array}$ & 59.57 & $\begin{array}{c}\text { Patchy parakeratosis, } \\
\text { epidermal hyperplasia, } \\
\text { absence of granular layer, } \\
\text { accumulation of neutrophil } \\
\text { in Malpighian layer, } \\
\text { elongation of rete ridges } \\
\text { and dilated capillaries in } \\
\text { superficial dermis } \\
\end{array}$ \\
\hline 2. & 党: & $\begin{array}{c}5, \\
(16.6 \%)\end{array}$ & 30.2 & $\begin{array}{c}\text { Intercellular oedema in } \\
\text { epidermis with mild } \\
\text { perivascular inflammatory } \\
\text { infiltrate including mast } \\
\text { cells, basophils and } \\
\text { eosinophils }\end{array}$ \\
\hline 3. & 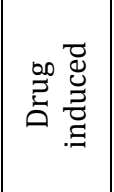 & $3,(10 \%)$ & 55 & $\begin{array}{c}\text { Epidermal spongiosis, } \\
\text { Lichenoid interface } \\
\text { dermatitis, occasional } \\
\text { eosinophils in upper } \\
\text { dermis }\end{array}$ \\
\hline 4. & 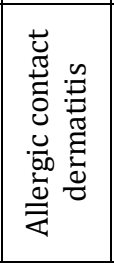 & $3,(10 \%)$ & 47.6 & $\begin{array}{c}\text { Spongiotic epidermis, } \\
\text { hyperkeratosis, } \\
\text { hypergranulosis, uniform } \\
\text { acanthosis, dermal oedema, } \\
\text { superficial perivascular } \\
\text { infiltrate with lymphocyte } \\
\text { and eosinophils }\end{array}$ \\
\hline 5. & 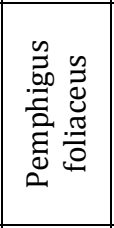 & $1,(3.3 \%)$ & 48 & $\begin{array}{c}\text { Bulla shows Subcorneal } \\
\text { cleft, acantholytic cells. Old } \\
\text { lesions showed acanthosis, } \\
\text { mild degree of } \\
\text { hyperkeratosis and } \\
\text { papillomatosis }\end{array}$ \\
\hline 6. & 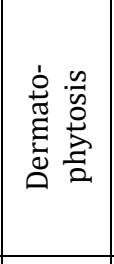 & $1,(3.3 \%)$ & 59 & \begin{tabular}{|} 
Hyperkeratosis, patchy \\
parakeratosis, \\
hypergranulosis, \\
spongiosis, mild acanthosis, \\
dermal perivascular \\
infiltrate of lymphocytes \\
and histiocytes \\
\end{tabular} \\
\hline 7. & 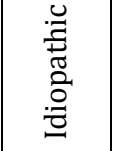 & $3,(10 \%)$ & 66 & $\begin{array}{l}\text { Mild spongiosis and non- } \\
\text { specific inflammatory } \\
\text { infiltrate }\end{array}$ \\
\hline \multicolumn{5}{|c|}{ Table 1} \\
\hline
\end{tabular}

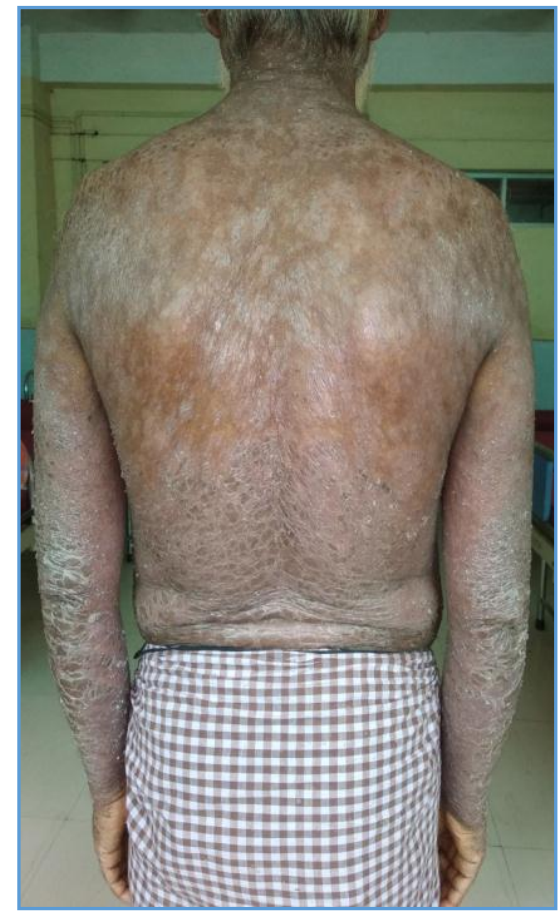

Figure 1. Psoriatic Erythroderma

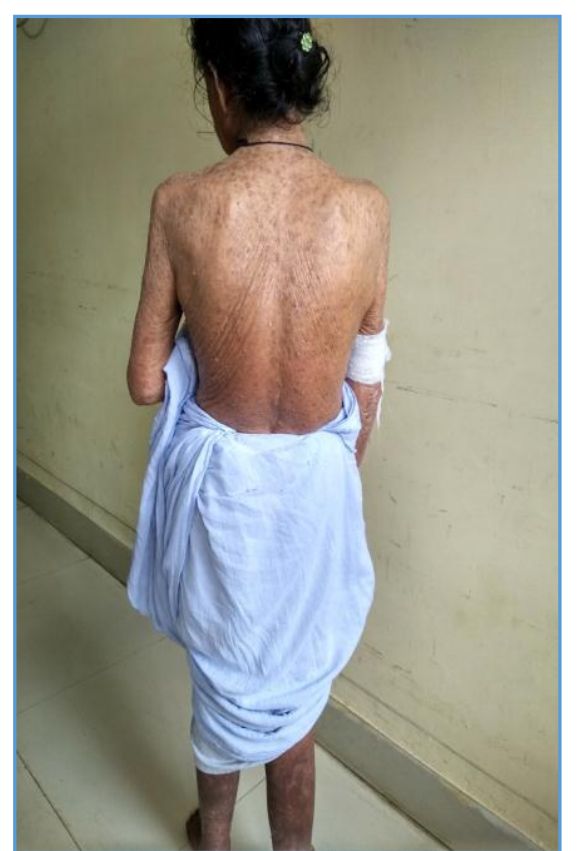

Figure 2. Erythroderma due to Atopic Dermatitis

\section{DISCUSSION}

Erythroderma is a rare exfoliative skin disorder, the true incidence of which remains unknown. A survey of dermatologists from the Netherlands estimated the annual incidence at 0.9 per 100,000 population. ${ }^{3}$ There is a male predominance in most studies with male-to-female (M: F) ratio ranging from 2: 1 to $4: 1$ and the mean age between 4060 years. $^{4}$ This is similar to our study, where the male-tofemale ratio was 2.3: 1 with mean age of incidence of 53.26 years.

A major challenge lies in determining the aetiology of erythroderma. A pre-existing dermatosis is the single most common cause of erythroderma as determined by most published series. 5 The most common cause of these 
dermatosis in Spanish, Middle Eastern and Indian studies include psoriasis and eczema. ${ }^{6-11}$ The triggers for precipitating erythroderma in psoriatic patients are withdrawal of systemic or topical glucocorticoids, use of systemic medications like lithium and antimalarials, phototherapy burns, infection and systemic illnesses. ${ }^{12}$ In our study, most of the psoriasis patients presented with history of irregular use of medication or sudden stoppage of medication. Drug reactions leading to erythroderma were seen in $11.2 \%$ cases in a study by Rym et al, $12 \%$ cases by Bandyaopadhyay et al, $32.7 \%$ cases by Nadia Shirazi et al, $40 \%$ cases in P Nupur et al, whereas in our study we found only $10 \%$ cases of drug-induced erythroderma.2,6,13,14 This group of patients had good prognosis with rapid resolution of lesions on discontinuation of offending drugs.

In a study done by $\mathrm{P}$ Nupur et al shows male: female ratio of 3: 2, age group range from 14 - 78 yrs., mean age of incidence 36 yrs. Atopic dermatitis cases reported as $20 \%$, psoriatic erythroderma cases 30\%, mean age of incidence 42 yrs., allergic contact dermatitis case $2 \%$, mean age 25 yrs., Pityriasis rubra pilaris $4 \%$ and mean age 35 yrs. ${ }^{14}$

In another study done in south India by Hulmani et al, the mean age of onset was 52.3 years with a male-to-female ratio of 14: 1 . Psoriasis was the most common (33.3\%) disease followed by eczema (20\%), atopic dermatitis (6.6\%), Pityriasis rubra pilaris $(3.3 \%)$ and drug-induced erythroderma (16.6\%). In $16.6 \%$ of cases, aetiology could not be ascertained. ${ }^{5}$

In one study done in north India by Nadia Shirazi et al, the mean age of presentation was 39.3 years and male-to-female ratio was 3: 2 . In their study, the most common aetiology of exfoliative dermatitis was drug reactions $(n=19,32.7 \%)$ followed by atopic dermatitis $(n=12,20.6 \%)$ and erythrodermic psoriasis $(n=10,7.2 \%)$. Other causes were Mycosis fungoides, Allergic/ Airborne contact dermatitis, Lichen planus and Pityriasis rubra pilaris. ${ }^{2}$

Though the clinical presentation of erythroderma is relatively uniform, histopathological characteristics of underlying lesion are usually distinctive. ${ }^{15}$ The exact underlying pathogenesis of erythroderma is not clear. It is believed that there may be role of cytokines, cell adhesion molecules including interleukins 1 and 2 , intercellular adhesion molecules (ICAM-1) and Tumour Necrosis Factor (TNF). ${ }^{16}$ Their interactions lead to a high epidermal turnover rate causing increased mitotic activity and increased absolute number of germinative skin cells. This is also associated with loss of epidermal cells together with superficial loss of protein and folate. ${ }^{17}$

It is of utmost importance to establish the cause of erythroderma. Drug-induced erythroderma shows a marked improvement once the causative drug is withdrawn, while those cases associated with a systemic disease will not improve unless the systemic disease is treated.

\section{CONCLUSION}

Erythroderma or exfoliative dermatitis is caused by various diseases including eczema of various subtypes, psoriasis, lymphoma, leukaemia, pemphigus foliaceus, lichen planus, dermatophytosis, crusted scabies, drugs including phenylbutazone, phenytoin, carbamazepine, gold salts, lithium, cimetidine, hereditary disorder like ichthyosiform erythroderma and pityriasis rubra pilaris also can lead to exfoliative dermatitis. ${ }^{1}$ Although, clinical presentation of most of the patients were similar, detailed history, physical examination and histopathological examination helped us to reach the diagnosis.

\section{REFERENCES}

[1] Ingram R. Eczematous disorders. In: Griffiths C, Barker J, Bleiker T, et al. eds. Rook's textbook of dermatology. Vol. 2. 9th edn. Blackwell Publishing 2016:111.1111.36.

[2] Shirazi N, Jindal R, Jain A, et al. Erythroderma: a clinico-etiological study of 58 cases in a tertiary hospital of North India. Asian Journal of Medical Sciences 2015;6(6):20-4.

[3] Sigudsson V, Steegmans PH, van Vloten WA. The incidence of erythroderma: a survey among all dermatologists in The Netherlands. J Am Acad Dermatol 2001;45(5):675-8.

[4] Sehgal VN, Srivastava G. Exfoliative dermatitis. A prospective study of 80 patients. Dermatologica 1986;173(6):278-84.

[5] Hulmani M, Nandakishore B, Bhat MR, et al. Clinicoetiological study of 30 erythroderma cases from tertiary center in South India. Indian Dermatol Online J 2014;5(1):25-9.

[6] Rym BM, Mourad M, Bechir Z, et al. Erythroderma in adults: a report of 80 cases. Int J Dermatol 2005;44(9):731-5.

[7] Akhyani M, Ghodsi ZS, Toosi S, et al. Erythroderma: a clinical study of 97 cases. BMC Dermatol 2005;5:5.

[8] Balasubramaniam P, Berth-Jones J. Erythroderma: 90\% skin failure. Hosp Med 2004;65(2):100-2.

[9] Botella-Estrada R, Sanmartin O, Oliver V, et al. Erythroderma. A clinicopathological study of 56 cases. Arch Dermatol 1994;130(12):1503-7.

[10] Pal S, Haroon TS. Erythroderma: a clinico-etiological study of 90 cases. Int J Dermatol 1998;37(2):104-7.

[11] Yuan XY, Guo JY, Dang YP, et al. Erythroderma. A clinicetiological study of 82 cases. Eur J Dermatol 2010;20(3):373-7.

[12] Rubins AY, Hartmane IV, Lielbriedis YM, et al. Therapeutic options for erythroderma. Cutis 1992;49(6):424-6.

[13] Bandyaopadhyay D, Chowdhury SN, Roy A. Seventy five cases of exfoliative dermatitis. Int J Dermatol 1999;44(2):55-7.

[14] Nupur P, Singh R. Erythroderma: a clinic-etiological study in a tertiary hospital. IJSR 2018;7(2):27-28.

[15] Zip C, Murray S, Walsh NM. The specificity of histopathology in erythroderma. J Cutan Pathol 1993;20(5):393-8.

[16] Wilson DC, Jester JD, King LE. Erythroderma and exfoliative dermatitis. Clin Dermatol 1993;11(1):6772.

[17] Hild DH. Folate losses from the skin in exfoliative dermatitis. Arch Intern Med 1969;123(1):51-7. 